\title{
Analisa Angin Zonal dan Meridional Dalam Menentukan Awal Musim Hujan di Kota Jambi
}

\author{
Presli Panusunan Simanjuntak*, Agus Safril \\ Prodi Klimatologi, Sekolah Tinggi Meteorologi Klimatologi dan Geofisika, Tanggerang Selatan, 15221 \\ *Email : presiisimanjuntak06@gmail.com
}

Diterima (08 September 2019), Direvisi (29 Januari 2020)

\begin{abstract}
In Indonesia, the prediction model for the beginning of the rainy season has not been intensively developed. Jambi City is the capital of Jambi Province as it has a large area of rainforest / fields and rain-fed rice fields and contributes considerably to Jambi province. The city of Jambi is in need of accurate predictions regarding the start of the rainy season to support increased budgets through agriculture and plantations. This study discusses wind components and zones at $1000 \mathrm{mb}$ at the beginning of the rainy season in the city of Jambi. Prediction of the start of the season using zonal and meridional winds will be divided into 2 current normal conditions of rainfall in 1997-2017 and during strong el nino conditions in 1997/1998 and 2015/2016. Based on data processing in 1997-2017 the beginning of the rainy season in December when the zonal wind speed is highest. In this study the wind component is more dominant than the meridional wind component in replacing the beginning of the rainy season. However, during the el nino condition, the zonal wind component is not good to be the first early rainy season in the Jambi region.
\end{abstract}

Keywords: el nino, meridional, zonal

Abstrak. Di Indonesia, model prediksi awal musim hujan belum banyak berkembang secara intensif. Kota Jambi merupakan ibukota Provinsi Jambi sebagai memilki lahan kebun/ladang dan sawah tadah hujan yang cukup luas dan berkontribusi yang cukup besar terhadap perekonomian Provinsi Jambi. Kota Jambi sangat memerlukan prediksi yang akurat mengenai awal musim hujan untuk mendukung kelangsungan perekonomian melalui pertanian dan perkebunan. Penelitian ini bertujuan menganalisa komponen angin zonal dan meridional pada lapisan $1000 \mathrm{mb}$ dalam menentukan awal musim hujan di kota Jambi. Prediksi awal musim menggunakan angin zonal dan meridional akan dibagi menjadi 2 kondisi yaitu saat kondisi normal curah hujan bulanan tahun 1997-2017 dan saat kondisi el nino kuat tahun 1997/1998 dan 2015/2016. Berdasarkan pengolahan data tahun 1997-2017 menunjukkan awal musim hujan adalah bulan Desember saat kecepatan angin zonal tertinggi. Dalam penelitian ini komponen angin zonal lebih dominan dibandingkan komponen angin meridional dalam penentuan awal musim hujan. Akan tetapi, saat kondisi el nino komponen angin zonal tidak baik untuk menjadi perkusor awal musim hujan di wilayah Jambi.

Kata kunci: el nino, meridional, zonal

\section{PENDAHULUAN}

Prediksi awal musim hujan adalah suatu informasi yang penting dan dibutuhkan dalam berbagai bidang, salah satunya adalah bidang pertanian dan perkebunan. Prediksi awal musim hujan dikeluarkan oleh Badan
Meteorologi dan Geofisika (BMKG) dan digunakan oleh Badan Penelitian dan Pengembangan Pertanian dan Perkebunan, Kementerian Pertanian untuk menyusun kalender tanam setiap tahunnya. 
Subsektor perkebunan dan pertanian mempunyai kontribusi yang cukup besar terhadap perekonomian Provinsi Jambi. Provinsi Jambi memiliki luas sawah tadah hujan 97.648 hektar atau sekitar $72 \%$ dari luas sawah keseluruhan dan memiliki luas kebun dan ladang 596.917 hektar [1], dari luasan tersebut Kota Jambi memiliki 1.349 hektar sawah tadah hujan dan 2.086 hektar kebun/ladang [2].

Di Indonesia, model prediksi awal musim hujan belum banyak berkembang. Dalam melakukan prediksi awal musim hujan, BMKG masih berdasarkan model prediksi curah hujan. Potensi galat atau sesatan dalam pemodelan tersebut akan sering terjadi yakni galat pada prediksi curah hujan dasarian dan galat dalam penentuan awal musim hujan [7].

Dalam beberapa penelitian menunjukkan adanya keterkaitan gerakan arah horizontal angin pada waktu dan wilayah tertentu dengan awal musim hujan di daerah lain, seperti penelitian oleh Zhao et al. [6] dengan menggunakan komponen angin zonal lapisan $850 \mathrm{hPa}$ untuk mendeteksi angin barat daya di timur Cina yang menjadi penanda munculnya awal musim hujan di tenggara Cina. Angin zonal merupakan komponen kecepatan timurbarat dari vektor angin. Junmei et al. [8] juga menghubungkan kecepatan rata-rata angin zonal lapisan $850 \mathrm{hPa}$ dengan curah hujan saat terjadinya Asian Summer Monsoon di daerah Cina dan Semenanjung Indocina. juga harus menunjukkan keunikan atau keistimewaan yang membedakan penelitian tersebut dengan penelitian-penelitian terkait, sehingga dibutuhkan referensi penelitian terkait sebagai pembanding.

Arah gerakan horizontal angin terbagi menjadi dua yaitu arah melintang dan membujur. Arah angin timur barat (lintang) disebut angin zonal dan arah angin selatan utara (bujur) disebut angin meridional. Angin zonal bergerak dari timur ke barat atau barat ke timur. Umumnya di wilayah
Indonesia, angin zonal yang bergerak menuju ke timur terjadi saat musim kemarau dan sebaliknya pada saat musim hujan angin zonal bergerak menuju ke barat dengan kecepatan 0 sampai $10 \mathrm{~m} / \mathrm{s}$.

Sedangkan angin selatan utara (bujur) disebut angin meridional . Angin meridional merupakan angin yang bergerak dari utara ke selatan atau dari selatan ke utara. Pada saat musim hujan kecepatan angin tersebut berkisar antara 0 sampai 10 meter/detik, sedangkan pada saat musim kemarau kecepatan angin berkisar antara 0 sampai 5 meter/detik. Proses gerakan angin ini akan mengalami kecepatan bervariasi dan berfluktuasi secara dinamis [5]. Pergantian musim di Indonesia mengakibatkan jumlah butiran curah hujan juga dipengaruhi oleh angin monsun [4]. Dampak adanya angin monsun di Indonesia adalah adanya angin baratan dan angin timuran. Angin baratan bertiup pada bulan Oktober hingga Maret, yang bertepatan saat terjadi monsoon dingin di asia. Angin ini membawa massa udara dingin dan lembab, sehingga menimbulkan hujan di berbagai lokasi yang terkena pengaruhnya. Angin timuran bertiup pada bulan April - September, bertepatan dengan monsoon panas Asia. Angin ini membawa massa udara kering menyebabkan musim kemarau bagi lokasi yang terkena pengaruhnya [3].

Berlandaskan kepentingan akan pembuatan prediksi awal musim hujan yang lebih baik dan sesuai untuk Kota Jambi menjadi tujuan utama penulis dalam melakukan penelitian ini dengan menggunakan prediktor angin zonal dan meridional lapisan $1000 \mathrm{mb}$ pada saat kondisi normal curah hujan dan saat kejadian El Nino kuat. 


\section{METODE PENELITIAN}

Prediktan yang digunakan adalah data curah hujan bulanan yang diperoleh dari data curah hujan harian tahun 1997-2017 kota Jambi yang diperoleh dari Stasiun Meteorologi Klas I Sultan Thaha Jambi.

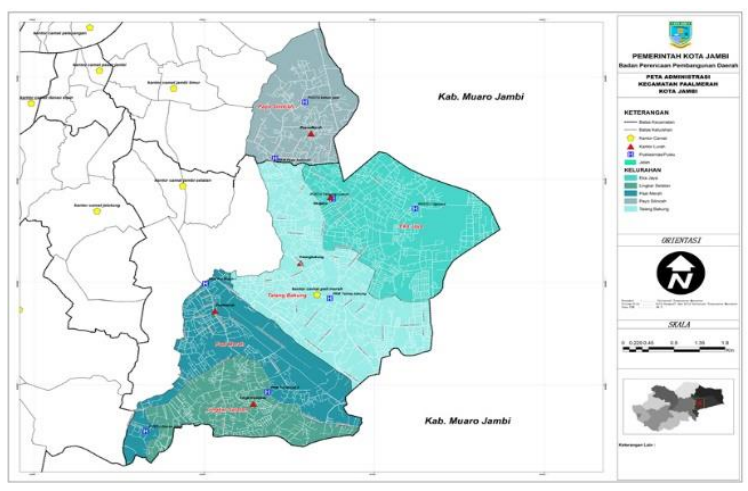

Gambar 1. Daerah Penelitian (Kota Jambi)

Prediktor yang digunakan adalah data angin zonal dan meridional yang diperoleh dari European Centre for Medium-Range Weather Forecast (ECMWF) tahun 19972017 dengan resolusi $0.125 \times 0.125$ dengan mengambil lokasi Indonesia yang kemudian menggunakan perangkat lunak BEAM VSAT Version 5.0 dipilih wilayah penelitian yaitu Kota Jambi yang terletak pada koordinat $1^{\circ} 35^{\prime} 21^{\prime \prime} \mathrm{LU} \quad 103^{\circ} 36^{\prime} 36^{\prime \prime} \mathrm{BT}$. Diagram alir pengolahan data dapat dilihat pada Gambar 2.

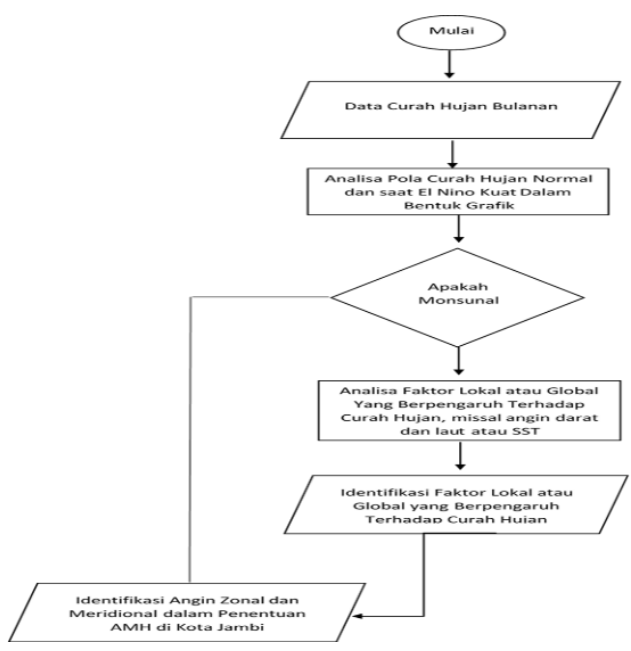

Gambar 2. Diagram Alir Penelitian

\section{HASIL DAN PEMBAHASAN}

\section{Analisa Angin Zonal Rata-rata Tahun 1997 - 2017}

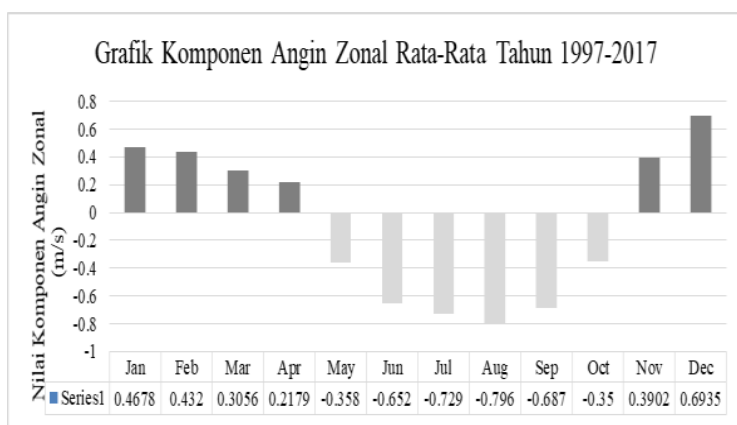

Gambar 3. Komponen Angin Zonal Rata-Rata Tahun 1997-2017

Berdasarkan grafik komponen angin zonal rata-rata tahun 1997-2017 untuk wilayah Kota Jambi, angin baratan terjadi pada periode November, Desember, Januari, Februari, Maret dan April sementara angin timuran terjadi pada periode Mei, Juni, Juli, Agustus, September dan Oktober. Untuk rata-rata kecepatan angin baratan adalah $0,418 \mathrm{~m} / \mathrm{s}$ sementara untuk kecepatan ratarata angin timuran adalah $0,595 \mathrm{~m} / \mathrm{s}$.

Kecepatan angin baratan tertinggi pada saat bulan Desember dengan 0,6935 m/s sedangkan kecepatan angin minimum terendah terjadi saat bulan April yaitu $0,2179 \mathrm{~m} / \mathrm{s}$. Untuk kecepatan angin timuran tertinggi terjadi pada saat bulan Agustus dengan kecepatan $0,796 \mathrm{~m} / \mathrm{s}$ dan terendah saat bulan Oktober dengan $0,35 \mathrm{~m} / \mathrm{s}$.

Untuk pola musiman periode Desember, Januari, Februari (DJF) adalah kondisi saat angin baratan dengan kecepatan rata-rata $0,531 \mathrm{~m} / \mathrm{s}$, MAM adalah kondisi saat peralihan dimana pada kondisi ini angin baratan dan timuran terjadi (Maret dan April, angin baratan dan Mei adalah angin timuran). Periode musiman Juni, Juli dan Agustus (JJA) terjadi angina timuran dengan rata-rata kecepatan angin 0,726 dan puncaknya pada Agustus.

Pada periode September, Oktober dan November (SON) juga adalah kondisi saat 
peralihan menuju pola angina baratan dimana September dan Oktober adalah kondisi angin timuran dan November adalah kondisi angin baratan.

\section{Analisa Angin Zonal Rata-rata Tahun $1997-2017$}

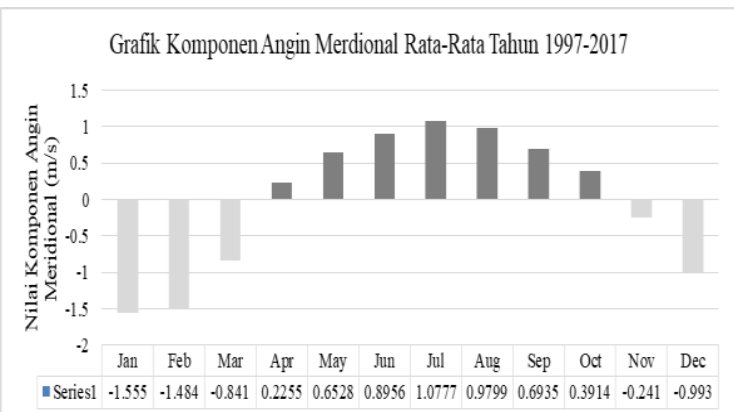

Gambar 4. Komponen Angin Meridional Rata-Rata Tahun 1997-2017

Berdasarkan grafik komponen angina meridional rata-rata tahun 1997-2017 untuk wilayah Kota Jambi, angin utara terjadi pada periode April, Mei, Juni, Juli, Agustus, dan September atau meridional positif dan untuk angin selatan atau meridional negative terjadi pada periode November, Desember, Januari, Februari, dan Maret.

Rata-rata kecepatan angin utara adalah $0.7663 \mathrm{~m} / \mathrm{s}$ sementara untuk kecepatan ratarata angin selatan adalah $1.0228 \mathrm{~m} / \mathrm{s}$. Kecepatan angin selatan tertinggi pada saat bulan Januari dengan kecepatan $1.555 \mathrm{~m} / \mathrm{s}$ sedangkan kecepatan angin selatan minimum terendah terjadi saat bulan November dengan kecepatan $0.241 \mathrm{~m} / \mathrm{s}$. Untuk kecepatan angin utara tertinggi terjadi pada saat bulan Juli dengan kecepatan $1.0777 \mathrm{~m} / \mathrm{s}$ dan terendah saat bulan April dengan kecepatan $0.2255 \mathrm{~m} / \mathrm{s}$.

\section{Curah Hujan Tahun 1997 - 2017 Kota Jambi}

Berdasarkan grafik diatas pola hujan di Kota Jambi adalah pola monsunal, Pola monsunal dicirikan oleh distribusi curah hujan bulanan berbentuk V. Rata-rata curah hujan normal di Kota Jambi adalah 170 mm. Kondisi saat Desember Januari Februari (DJF) adalah periode musim hujan dengan rata-rata curah hujan $203 \mathrm{~mm}$.

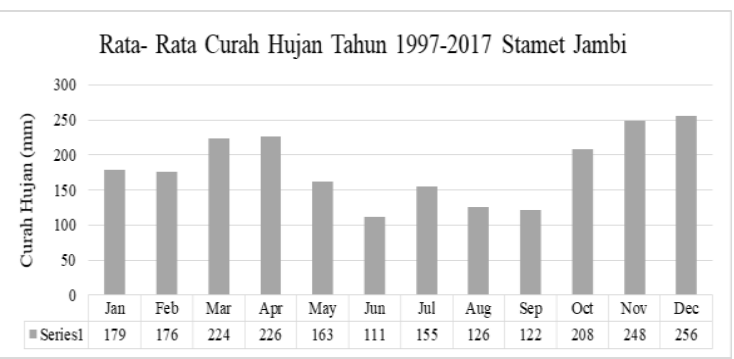

Gambar 5. Rata-Rata Curah Hujan Tahun $1997-$ 2017

Kondisi curah hujan melimpah diikuti pada bulan Maret dan April yang berkisar diatas 200mm akan tetapi intensitas curah hujan menurun pada bulan Mei dengan curah hujan rata-rata 163 . Periode musim kemarau adalah saat periode musim Juni Juli Agustus (JJA) dimana rata-rata curah hujan berada dibawah normal dengan rata-rata 131 $\mathrm{mm}$. Musim peralihan menuju musim hujan berada saat periode September Oktober dan November, dimana curah hujan semakin meningkat hingga memasuki musim hujan DJF, dengan rata-rata Curah hujan SON adalah $193 \mathrm{~mm}$.

\section{Hubungan Angin Zonal dan Meridional Terhadap Normal Curah Hujan Bulanan}

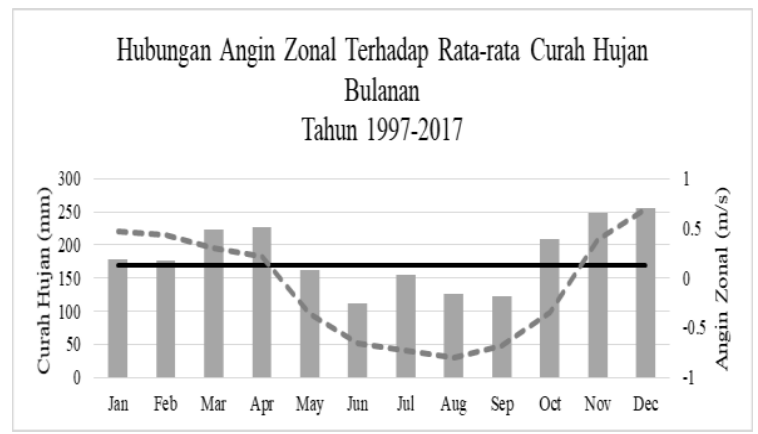

Gambar 6. Hubungan Angin Zonal Terhadap Rerata CH Bulanan 


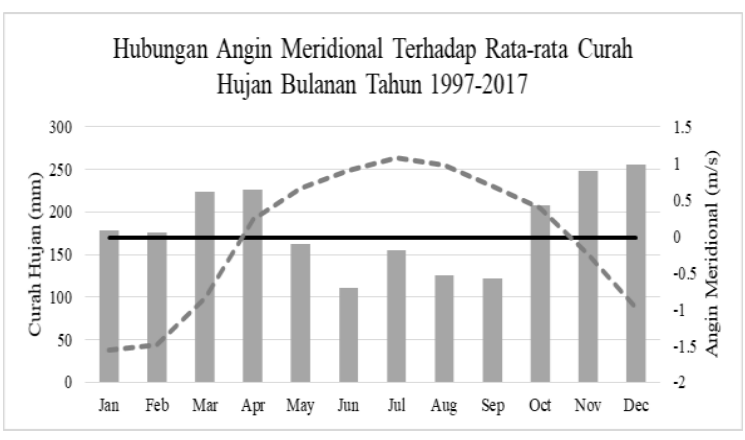

Gambar 7. Hubungan Angin Meridional Terhadap Rerata CH Bulanan

Pada dinamika atmosfer wilayah tropis Indonesia, Angin Zonal lebih dominan pengaruhnya terhadap pola hujan yang terjadi dibandingkan angina meridional. Untuk Kota Jambi, pola angina zonal yang sangat mempengaruhi pola hujan diwilayah ini dibandingkan kondisi angina meridionalnya. Pola monsunal dicirikan oleh distribusi curah hujan bulanan berbentuk $\mathrm{V}$ dengan jumlah curah hujan musiman rendah pada bulan Juni, Juli atau Agustus.

Pada kondisi normal, saat monsun barat akan mendapat curah hujan yang berlimpah (musim hujan) sedangkan pada saat monsun timur jumlah curah hujannya sangat sedikit (musim kemarau). Pada pola hujan monsunal wilayah Jambi memiliki perbedaan yang jelas antara periode musim hujan dan periode musim kemarau. Secara umum musim kemarau berlangsung dari April sampai September dan musim hujan dari Oktober sampai Maret.

Tipe grafik curah hujan bersifat unimodial (memiliki satu puncak musim hujan). Puncak maksimum musim hujan yaitu pada bulan Januari / Desember. Sementara itu lembah minimum terjadi pada bulan Agustus pada saat musim kemarau. Tipe monsunal dipengaruhi oleh angin musiman (monsun). Saat kondisi angina baratan wilayah Jambi akan mengalami peningkatan Curah Hujan, sementara saat kondisi angina timuran wilayah Jambi akan mengalami penurunan jumlah curah hujan. Untuk kondisi angina meridional. Saat angina selatan yang berhembus korelasinya akan mengurangi intensitas curah hujan diwilayah Jambi dan saat angina utara yag berhembus berkolerasi positif dengan peningkatkan curah hujan.

\section{Hubungan Angin Zonal dan Meridional Terhadap Curah Hujan Bulanan Pada Saat EI Nino Kuat}

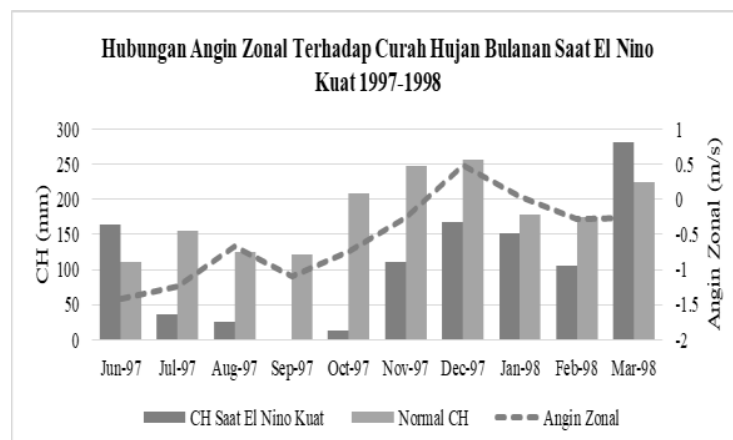

Gambar 8. Hubungan Angin Zonal Terhadap Rerata CH Bulanan Saat El Nino Kuat 19971998

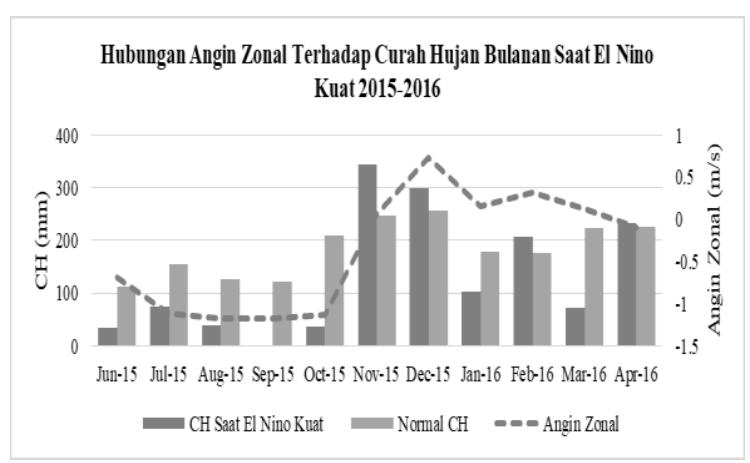

Gambar 9. Hubungan Angin Zonal Terhadap Rerata CH Bulanan Saat El Nino Kuat 20152016

Dalam kaitannya dengan El-Nino, tinjauan banyak dilakukan terhadap angin zonal karena komponen itulah yang dominan dalam menentukan atau mengindikasikan terjadinya El-Nino. Seperti sudah diketahui, pada kondisi normal, angin pasat di sepanjang Pasifik dekat ekuator akan 
berhembus ke arah barat. Ketika terjadi ElNino, angin ini akan melemah dan cenderung berbalik arah ke timur, sehingga massa air panas akan terbawa ke Samudera Pasifik tengah dan timur dekat ekuator (daerah Nino) dan membentuk kolam air hangat di sana.

Secara umum berdasarkan Gambar 8 dan Gambar 9 pola angin zonal saat bulan dengan el nino kuat (Jun-97 s/d Mar-98 dan Jun-15 s/d Apr-16) dan angin zonal saat kondisi normal tidak ada perubahaan signifikan. Kondisi El Nino tidak menyebabkan perubahaan signifikan terhadap pergerakan arah angina zonal di wilayah penelitian. Akan tetapi pola curah hujan saat terjadi El Nino kuat dengan saat kondisi normal mengalami pergeseran. Saat kondisi normal Desember Januari Februari (DJF) adalah kondisi musim hujan diikuti Maret dan April kemudian pada bulan Mei curah hujan akan menurun dan memasuki musim kemarau pada periode Juni Juli Agustus (JJA), Curah hujan perlahan akan meningkat pada bulan September Oktober November.

Berdasarkan Gambar 8, Curah hujan saat el nino kuat pada tahun 1997-1998 mengalami penurunan intensitas sekitar 75 $\mathrm{mm}$ dan September Oktober November (SON) yang seharusnya sudah memasuki musim peralihan ke musim hujan dengan rata-rata Curah hujan periode SON adalah $193 \mathrm{~mm}$ mengalami penurunan intensitas rerata curah hujan menjadi $41 \mathrm{~mm}$ dan awal musim hujan yang seharusnya DJF saat normal adalah $203 \mathrm{~mm}$ mengalami penurunan intensitas rerata curah hujan 141 mm. Awal Musim hujan bergeser dari Desember menjadi Maret. Berdasarkan Gambar 9 . Curah hujan saat el nino kuat pada tahun 2014-2015 mengalami penurunan intensitas sekitar $50 \mathrm{~mm}$. Saat El Nino kuat tahun 2014-2015 awal musim hujan mengalami pergeseran menjadi November.

\section{KESIMPULAN}

1. Pola hujan di Kota Jambi adalah monsunal yang memiliki perbedaan yang jelas antara musim hujan dan musim kemarau. Awal Musim Hujan kondisi normal adalah bulan Desember dengan periode musim hujan adalah Desember Januari Februari. Awal Musim Kemarau kondisi normal adalah bulan Juni dengan periode musim Kemarau adalah Juni Juli Agustus.

2. Angin zonal lebih dominan dibandingkan angin meridional di wilayah penelitian.

3. Angin Zonal dapat dijadikan perkusor dalam penentuan awal musim hujan di wilayah penelitian.Saat angin zonal baratan awal aktivitas monsun barat di mulai pada bulan November sampai dengan April. Saat angin zonal tmuran awal aktivitas monsun timur di mulai pada bulan Mei sampai dengan Oktober.

4. Saat kondisi EL Nino kuat, pola angin zonal tidak mengalami perubahaan yang signifikan dibandingkan pola angin zonal saat kondisi normal.

5. Perkusor angin zonal dan meridional tidak dapat digunakan dalam penentuan awal musim hujan saat terjadi el nino kuat.

\section{DAFTAR PUSTAKA}

[1] Badan Pusat Statistik Provinsi Jambi, Provinsi Jambi Dalam Angka 2017, Jambi : BPS, 2018

[2] Badan Pusat Statistik Provinsi Jambi, Kota Jambi Dalam Angka 2017, Jambi : BPS, 2018 
[3] Nieuwolt, S., Tropical Climatology. New York: John Wiley and Sons Inc, 1987

[4] Rafi'i, Suryatna, Meteorologi dan Klimatologi, Bandung: Penerbit Angkasa, 1995.

[5] Sandy, L. M., Klimatologi Regional Indonesia, Depok: Jurusan Geografi FMIPAUI, 1987

[6] Lo F, et al., Probabilistic Forecasts of the Onset of the North Australian Wet Season, American Meteorological Society Monthly Weather Review, vol.135, pp. 35063520, 2007
[7] Virgianto, R.H., Prediksi Awal Musim Hujan Dengan Prediktor Anomali Angin Zonal dan Anomali Suhu Muka Laut (Studi Kasus Kabupaten Banjar di Kalimantan Selatan), Prosiding Semirata IPB Vol.7, 2014.

[8] Zhao. P., Onset of Southwesterly Wind over Eastern China and Associated Atmospheric Circulation and Rainfall, Journal of Climate Dynamics, vol. 28, pp. 797-811, 2007. 
Presli dkk.: Analisa Angin Zonal dan Meridional Dalam Menentukan Awal Musim Hujan di Kota Jambi 